\section{Saturday night palsy}

Helga Peter

Marburg, Deutschland

\section{Definition}

Schlafinduzierte passagere Dysfunktion eines peripheren Nervs durch Druckschädigung; wird gehäuft unter erheblichem Alkoholkonsum bzw. unter Drogeneinfluss am Wochenende erworben.

Siehe auch $\triangleright$,Nervenlähmung, druckbedingte“. 